\title{
RUSSIAN LITERATURE AND THOUGHT
}

Gary Saul Morson,

Series Editor 


\title{
RELATED TITLES
}

\author{
1920 Diary \\ Isaac Babel
}

The Lower Depths and Other Plays

Maxim Gorky

Stalin's Letters to Molotov

Josef Stalin

A History of Russian Literature

Victor Terras

$A$ Voice from the Chorus

Abram Tertz (Andrei Sinyavsky)

Strolls with Pushkin

Abram Tertz (Andrei Sinyavsky) 


\section{MAXIM GORKY}

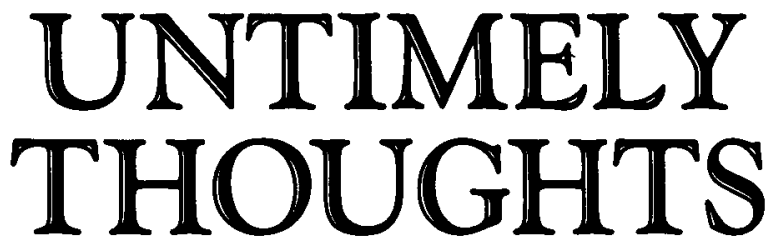

ESSAYS ON REVOLUTION, CULTURE AND THE BOLSHEVIKS

1917-1918

With a new introduction and chronology

by Mark D. Steinberg

Translated from the Russian and with notes by Herman Ermolaev

Yale University Press

New Haven \& London 
Originally published 1968 in the United States by Paul S. Eriksson, Inc. Paperbound edition published 1995 by Yale University Press

Copyright $\mathcal{Q} 1968$ by Herman Ermolaev

New introduction and chronology

Copyright $(\mathcal{O} 1995$ by Yale University

All rights reserved.

This book may not be reproduced, in whole or in part, including illustrations, in any form (beyond that copying permitted by Sections 107 and 108 of the U.S. Copyright Law and except by reviewers for the public press), without written permission from the publishers.

Printed in the United States of America by BookCrafters, Inc., Chelsea, Michigan.

Library of Congress Card Catalogue Number: 94-61488

International standard book number: 0-300-06069-6 (pbk.)

A catalogue record for this book is available from the British Library.

The paper in this book meets the guidelines for permanence and durability of the Committee on Production Guidelines for Book Longevity of the Council on Library Resources. 